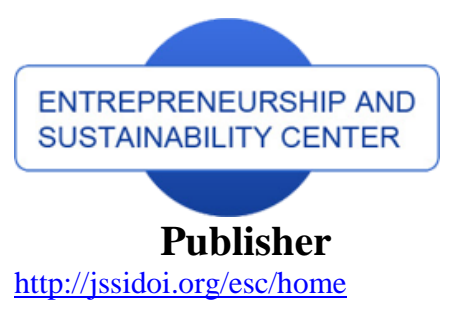

http://jssidoi.org/esc/home

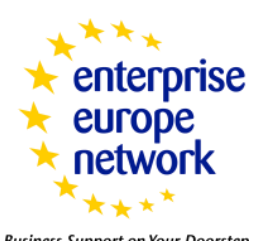

Business Support on Your Doorstep

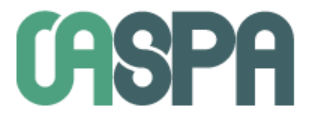

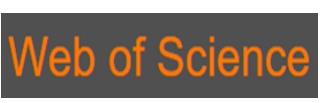

I Clarivate

\title{
BANKING PERFORMANCE OF CHINA AND PAKISTAN
}

\author{
Jia Xin Xu' ${ }^{1}$, Naiwen Li ${ }^{2}$ Muhammad Ishfaq Ahmad ${ }^{3}$ \\ ${ }^{1,2}$ School of Business Administration, Liaoning Technical University, P.R China \\ ${ }^{3}$ Lahore Business School, The University of Lahore, Pakistan \\ E-mails:11157196058@qq.com; ${ }^{2} 570915380 @ q q . c o m ;{ }^{3}$ _m_ishfaq452@yahoo.com
}

Received 20 January 2018; accepted 18 April 2018; published 30 June 2018

\begin{abstract}
This study aims to investigate the comparative performance of the banks of the china and Pakistan, as both countries have very strong business relationships apart from the strategic relationships. The recent investment contracts between two countries "One Belt One road" worth $\$ 54$ billion motive me to do examine the comparative performance of Chinese and Pakistani banks as banks do have vital role in this regard. To give first sight understanding of the objectives of the study, I choose the title which explains the objectives of the study clearly as starting with the comparative study of the banking performance of both countries. As the banks play a magnificent role in an economy for the smooth as well as efficient functioning of the different activities of the society. The importance of the banking could be realized by taking the example of the blood in human body as banks provides blood to the economy of any country. Due to their important role, it is strong need to keep banking sector healthy and stable which is not possible without the continuous focus on it. Recent economic crunch has highlighted that a well-established financial system is the basic ingredient for the economic growth. So it is very important to know what factors derive the performance of the banks. This study main focus is to identifying the factors determining the profitability of the Chinese and Pakistani banking sector. China becomes the economic hub for rest of the world and Chinese banking is also growing significantly. The importance of the Chinese banks could be realized that four Chinese banks are ranked among the top big firms of the world. The study used the Chinese and Pakistani banking sector sample which includes all kinds of banks over the time span of 2010 to 2017. The Chinese banking sample consists of forty four banks while Pakistani banks sample consists of twenty one banks. We observed that Chinese banking profitability which is measured through the Return on Assets (ROA) and Return on Equity (ROE), is positively influenced by the net interest income, deposits, Capital adequacy ratio and GDP growth while non-performing loans are significantly contribute to the performance of the Chinese banking. This relationship exist the same in the Pakistani banking industry. Moreover we found that Chinese banks are performing better than the Pakistani banks because of their big size, higher growth in GDP and due to the government ownership. Furthermore I also conclude this is the golden time for the Chinese banks to go across the border to gain the lucrative opportunity in the Pakistan as the Gawader Seaport is managed by the Chinese government to channel their trade to the Europe. By doing so they cannot only increase their Chinese market share but international market share. Moreover we found that Chinese listed banks perform much better than the unlisted banks of china. Although some unlisted banks perform nicely but overall listed banks produced sound results. Through getting listed and managing the financial resources, they can do cross border business either by mergers, joint ventures or acquisition to overcome the cultural issues. In the case of Pakistan, we observed that foreign banks beat both the domestic private banks and state owned banks. We ranked domestic private banks at number two and state banks performed poorly in case of Pakistan. In the Comparison of Chinese and Pakistani bank, Chinese banks are better than Pakistani banks the factors for the performance react in the same way.
\end{abstract}


Keywords: Banks' performance; Return on Equity (ROE); Non-performing loans; Listed banks; GDP

Reference to this paper should be made as follows: Xu, J. X.; Naiwen, L.; Ahmad, M. I 2018. Banking performance of China and Pakistan, Entrepreneurship and Sustainability Issues 5(4): 929-942. http://doi.org/10.9770/jesi.2018.5.4(16)

JEL Classifications: $\mathrm{G} 2$ and G21

\section{Introduction}

Banks are quite important for any society as they are developing the economies by facilitating the business. Banks are around us since the first currencies minted. Currency, particularly the use of coins, grew out of taxation. These coins need to be put in safe place, so ancient homes were not safe so most healthy people held their accounts in temples. There are examples of from Greece, Rome, Egypt and Ancient Babylon that suggest temples loaned money out, in addition to keeping it safe. This was the need of development of the banks to let people save their wealth.

The existence of banks is primary important for us, as with the exception few people can do cash transaction for our basic need like homes. We need support from banks in the form of mortgage or credit facilities to fulfill our daily needs. It would be worthwhile to say here that the world cannot run smoothly without the credit and effective banking system. So for the existence of effective banking system, there is a strong need that banks perform their functions properly to maximize the wealth of the depositors which is not possible without earning reasonable profit.

China being a fastest growing economy has went through rapid economic growth over the past three decades. During this era, banking reforms plays significant role in the economic development. Chinese banking sector was monopolized by the People's Bank of China back till 1979. During the 1980 four state owned banks came into existence named Bank of China (BOC), Industrial commercial Bank of China (ICBC), Agricultural Bank of China $(\mathrm{ABC})$ and China Construction Bank (CCB). The operation of each bank is strictly confined to a given division. From 1998, the state owned specialized banks had been transformed to commercial banks. The People's Republic bank serves as the Central bank of China to manage the money supply through series of monetary policies. Later on with the passage of time, commercial banks started shareholding reforms for the sake of better efficiency and corporate governance. After stripping off bad assets and two round of capital injection in 1998 and 2003, the government took the initiative to transform commercial banks into joint -stock entities. This step gave the way to Chinese banking embarked on the path of "marketization". Later on threefold improvement towards liberalization of the banking system played significant role in shaping the decent banking system. First globally market oriented and modern corporate governance practices welcomed and implemented in the banking business. Secondly government promotes the banking by introducing bank-favored interest spread policies. In the last since 2007, the Chinese government opens door for the foreign players and allowed them to work in the Chinese Currency. The opening doors for the international players foster the efficiency and competition among the domestic banks. By 2010, all state owned banks successfully completed the Initial Public Offering and transformed into listed companies. Meanwhile these reforms significantly boost the financial efficiency of the Chinese banking industry. According to the report of "The Banker", till 2016 Four Chinese banks, ICBC, China Construction Bank, Bank of China and Agricultural Bank of China are all in the top five banks by Tier 1 capital worldwide. "But the good news does not end there for Chinese banks, with many putting in a strong performance further down the ranking" Stefania Palma (2016). The liberty in the banking sector era, foreign banks went on massive expansion in terms of financial institutions and total assets (see Table 1). 
The supervision of foreign subsidiary banks and branches has been developed in three stages. Till 1994, there was limited opening degree of financial industry. The operations of the foreign subsidiary banks was limited to the foreign exchange business of foreign-invested enterprise and in the region of shanghai and Shenzhen. The "Regulations of the People's Republic of China Governing Financial institutions with Foreign Capital" (1994) allows foreign subsidiary banks to open foreign currency operations and throughout the china. In Nov.2011, China Joined the World Trade Organization (WTO) and react in the financial markets as per the commitments of the WTO.

The "Regulations of the People Republic of China on Administration of Foreign-funded Financial Institutions (2011)" and "Detailed Rules for the Implementation of the Regulation of the People's Republic of China on the Administration of Foreign-Funded Financial Institutions (2004)" gave freedom on the foreign exchange business, either in geographical or customer types. However, foreign subsidiary banks started their operations with special licenses and limitations. The regulator provided a national treatment to foreign subsidiary banks and branches, but only for foreign currency businesses. After 2006, both foreign and local currency businesses were fully opened for subsidiary banks and branches without any restriction. Foreign banks started to collect deposits from the public without any restrictions i.e. Licenses or permissions. Invention of modern and innovative financial products was supported by replacing the approval system with the record system which facilitated the product innovation. Meanwhile Basel Core Principles was treated as reference. No doubt foreign banks had their own predominance in Retail banking, foreign exchange business and financial Innovation and intermediary.

The history of Pakistani banking sector is witness to various interesting phases. The first phase starts from the Independence Day march 1947 when there were 3496 offices of Indian scheduled banks out of which 487 were situated in territories now constituting Pakistan. Pakistani banking industry suffers heavy losses due to uncertainty and unsuitability. To put pressure and collapse the new born state many Indian banks closed their offices in Pakistan which shrunk this industry from 487 banks to 195 branches by 1948. During 1971-1972's, new government introduced reforms to promote economic growth through social justice. The objective of these reforms was to make equitable distribution of credit to increase the efficiency and soundness of banks along with social accountability. Banks could not perform their role in social justice, for example credit was given to big accounts and urban area which resulted in shortage of credit in agricultural, small businesses and emerging exports and housing. This attitude of banks forced government to come forward with reforms. Under these reforms State bank of Pakistan got wider powers through which state bank of Pakistan can take some administrative measures. If a director could not fulfill his obligation state bank can fire him/her. Moreover, it was laid down that no person could serve as director of a bank for more than six years continuously. Meanwhile State bank of Pakistan introduced reforms for the establishment of new institutions. More importantly people's Finance Corporation was setup to encourage small business while National Development Finance Corporation established for public and managed industries and enterprises.

After eighteen months of above said reforms, Government of Pakistan nationalized banks with the following objectives: to use the capital concentrated in few rich banks not for the rapid economic growth but urgent social welfare objective also; to made sure the equability credit to various sectors of economy. The act passed by national assembly of Pakistan is known as "Nationalization Act 1974" This was a U turn for Pakistani economy, because by this act, the Chairman, Directors and Executives of various banks which are not appointed by the federal governments are supposed to leave banks. All exiting central and local bodies were dissolved and for the management of these nationalized banks, Pakistan banking council was setup. At that moment there were 14 commercial banks with 3323 offices allover Pakistan and 74 offices in foreign countries were nationalized. During 1991 when it was realized that the role of national banks in the economy over extended which are adversely affecting the growth and efficiency of financial sector. Due to government ownership, political 
intervention into credit allocation and recovery became the big challenge besides the other inefficiencies. As a result there was massive increase in bad loans and banks suffered heavy losses. To respond this issue several policy reforms were undertaken to motivate private sector in this industry. The main objective of these reforms was to improve the efficiency level along with the competition in this market. This act empowered the federal government to sell full or part of share capital in national banks. Through this act governments not only sold the share capital of state owned banks but also welcomed the new banks to strengthen the competition in the market. As a result within two year 11 new banks entered in Pakistani banking industry.

\section{Problem Statment}

Recent economic crunch has highlighted that a well-established financial system is the basic ingredient for the economic growth. It enables an economy to be flourishing as it facilitates investors with few resources to utilize savings from those with few prospect of investing. In this regard it is crucial to know what factors derives banking profitability. Higher profitability not only accelerate more financing to the economy it is also good for regulators as it guarantees more flexible capital ratios. Additionally higher profitability must lead to higher returns to shareholders which is the ultimate goal of the management of any bank.

Despite all the above facts and the financial reforms in China and Pakistan taken since 1990s, with an aim of improving profitability, efficiency and productivity, banks performance has still remained poor concluded by (Francis 2010). A substantial amount of literature available that shows that poor performance manifest into lower performance of bank factors including poor quality of loans, operational in efficiencies, higher level of liquidity risk and higher amounts of non-performing loans ratios; among others. Although above said are main hurdles affecting Chinese banks performance (Qinwei Chi \& Wenjing Li 2017). In the same line Pan and Zhang, (2012) demonstrated that higher government ownership ratio is the cause of risk taking in different businesses. Shih et al. (2007) examined the profitability of the big four, joint stock and city commercial banks through principal analysis and concluded that joint stock banks are better than state owned banks. This lower profitability demonstrates the lack of competiveness in the Chinese banking sector. All these studies, among others show understanding on Chinese banking sector is important. There is strong need to explore what explains the profitability of the Chinese banking.

It would not be wrong to say here that Pakistani banking is the fastest sector of the economy. As per World Bank report, Pakistan has been ranked at second raked on the basis of performance among south Asian countries (Rehman \& Raoof, 2010). The competition in the banking industry is growing day by day. Higher pressure on Pakistani economy, political instability and continues changing monetary policies has increased the importance and challenges of this sector. Ramiz et.al (2016) examined the performance of the Pakistani banking and concluded that foreign banks are more profitable than both public and private banks. Moreover they concluded that non-performing loans had adverse affect on the profitability of banking sector of Pakistan. In the same direction as ramiz, Khizer et.al. (2011), concluded that profitability is directly derived by the asset management and operational efficiencies. Pakistani banking is more open as compared to the Chinese banking as there are many foreign banks operating in the Pakistan and the ratio of the state owned banks is significant less which is also the key of the fattest growing sector of the economy. So in this intense environment, banks with the poor performance could not survive for their better survival, banks needs to produce consistent and higher profitability.

Returning back to the Chinese banking sector, regardless of the continuous changes and reforms undertaken with an aim of liberalization of sector as recently i.e On December 8, 2016, China banking regulatory Commission (CBRC) announcement "Private Banks Gained Great Progress in Enhancing the Quality and Efficiency of Services for Real Economy", the concentration and profitability performance of the sector as compared to the prereform period, this sector is still suffering from the high competition and operational inefficiencies which is the indication of the poor performance. The same situation is existed in the case of Pakistani banking sector which 
The International Journal

ENTREPRENEURSHIP AND SUSTAINABILITY ISSUES

ISSN 2345-0282 (online) http://jssidoi.org/jesi/

2018 Volume 5 Number 3 (June)

http://doi.org/10.9770/jesi.2018.5.4(16)

undergone through several reforms over the past two decades. However, even if the aim of the financial reforms to improving the profitability, efficiency and productivity of the Chinese and Pakistani banking industry, both countries performance is still not up to the standard. There is much noise in the literature regarding the Chinese credit risk. According to the Standard \& Poor's, changing economic policies can affect the Chinese banking (Asia -Pacific News, 2015).

All above mentioned issues in the banking industry of China and Pakistan in relation to profitability in general and performance in particular with the gap in the literature with respect to performance and the connection between performance and internal and external factors call for the deeper investigation. Furthermore, for the minimization of above posed problems like credit risk, asset management, high liquidity and others related to the performance, identifying the factors affect the banking performance is vital. Therefore this thesis seeks to fill the room by providing the detailed information about internal and external factors affects performance by adding the untouched one and replacing the existing in the Chinese and Pakistani banking context.

In this study, we are going to identify the performance of Chinese and Pakistani banking. We are looking for adequate performance concept and its valuation. However, by applying evaluation process we are going to find the answer of the question "What are the determinants of bank's performance in China and Pakistan, and how do those factors influence the performance of Chinese and Pakistani banks"?

\section{Review of Literature}

The statement 'too-big- to fail' (TBTF) has been issue for decades in discussion of the banking regulations. This term came into existence in the insolvency of Continental Illinois back in 1984 (Völz and Wedow, 2011). Konstantinos et.al (2016) examined the relationship of the banks earning and size for the UK banks. They used the data of 2000 to 2012. They empirically find nonlinear relationship between the bank size and returns of the UK banks. Poghosyan and de Haan (2012) examined the US commercial, saving and cooperative banks over the period of 2004Q1 to 2009 Q4. By applying the econometric model, they conclude bank size is negatively related to the earning volatility. Similarly Luc Laeven et. al (2016) studied the influence of bank size, capital and systemic risk for the 412 deposit-taking institutions from 56 countries. By employing the Systemic risk regressions, they empirically concluded that bank size is inversely related to the capital of the banks. In the same line Stiroh (2004) examined the same relationship in the US banks and by taking large sample of banks he concludes that there is no link between return on Equity (ROE) and the size of bank. 419 US bank holding companies are examined by De Nicoló (2000). By utilizing the time span of 1988-1998, and finds that there is positive relationship between the Return and small and medium banks while negative relationship between size and larger banks. It gives the conclusion that larger banks do have negative relationship with return while small and medium size banks, there is positive relationship.

The recent 2008, global financial crises proved that financial stability has important role in financial system and especially in the banking sector, both in the developed and developing economies. A sound and profitable banking industry is better able to absorb the adverse shocks and ensure the stability of the financial system. In this way financial stability and monetary policy are closely linked as interest rates and other policy tools, has direct and indirect implications for bank profitability and financial system, as Alessandri and Nelson (2015) showed that bank profitability is a key determinant of the bank capital. Resul Aydemir et.al (2016) studied Interest rates, the yield curve and bank profitability in an emerging market economy in Turkish banking industry. They used the dynamic panel data of 26 commercial banks of turkey for the time span of 2002 to 2014. They concluded that there is a inverse relationship between the interest rates and banks profitability of the studied banks. However they also document that banks in emerging economies are more sensitive with respect to the interest rate as compared to the developed economies like UK. 
The primary aim of the banking regulation is to mitigating the systemic risk comes from the bank failures, to protect depositor's interest and maintaining the financial health of the whole economy. After the recent financial crisis, the US the US Board of Governors of the Federal Reserve System has support the Basel III proposal of the Basel Committee on Banking Supervision (BCBS) that states that there should be more stringent capital and liquidity requirements. Moreover along with the international support, it has been focusing on the strengthening the quantity quality of capital through more stringent minimum ratios (Basel Committee on Banking Supervision, 2010). Starting from the Heba Abou-El-Sood (2016) investigation if regulatory capital adequacy ratios good indicators of bank failure for US banking sector. The author uses the data of 560 US bank holding companies over the time span of 2003-2009, by employing the statistical model, the author documents that there is significant association between the capital adequacy ratio and banks failure.

Literature gives mixed results on the association of capital adequacy ratio and the probability of the bank failure. Furlong and Keeley (1989) investigate regulatory capital is fruitful for the stability of the banking system. They showed that banks with the higher capital ratio, exposure the lower risk. Berger et al. (1995) state that costs of failure are borne by the debt-holders and especially by common stock holders. Therefore debt holder's demands higher returns to offset the failure probability and shift that expected cost to the shareholders. In turn, shareholders mange this cost by increasing the regulatory capital to the point that the reduction in the expected likelihood of failure offsets the reduction in the tax benefits of debt. Bichsel and Blum (2004) study the association between the changes in capital ratios and changes in the level of risk and failed to find any association between the capital ratio and default probability.

China has had a long history with the non performing loans and it is assumed to be the major hurdle to the development of the domestic banks. In the literature Non performing loans bas been identified as the signals of future financial issue for the banks. Demirguc-Kunt (1989) and Barr et al. (1994) argued that failure banks always had higher level of nonperforming loans. Dayong Zhang et. al (2016) examined the Non-performing loans, moral hazard and regulation of the Chinese commercial banking system. They utilized the data of 60 city commercial banks, 16 state-owned banks and joint-stock banks, and 11 rural commercial banks over the time span of 20062012. They empirically showed that Non-performing loans causes riskier lending which ultimately leads to the financial instability.

Since 2003, apart from the Chinese banking reforms, the Chinese government inject significant amount of capital in Chinese banks to lower the amount of non-performing loans (Jiang et al., 2013), Furthermore according to the Chinese banking regulation commission (CBRC), the NPL ratio across all the banks has been maintained at satisfactory level which is two percent but does not give the guarantee that there would not be a serious problem in near future. Foos et al. (2010) argue that growth in the loan fruits in the form of loan losses during the upcoming three years which leads a decrease in the interest income and capital adequacy. Soedarmono and Tarazi (2015) show that greater market power in the bank sector might causes to financial instability in the Asia-Pacific context.

The empirical literature on the economic development indentified level of banking development and stock market development are among the most important factors across the countries (Fink, Haiss, \& Vuksic, 2009; Beck \& Levine, 2004; Garcia \& Liu, 1999; Levine \& Zervos, 1998; Naceur \& Ghazouani 2007; Yartey, 2008). Actually it is ongoing debate that poor countries with the less developed financial system are trapped in Vicious circle, where low development in banking sector and stock market, results in low economic performance and low economic performance leads to low financial development (Fung, 2009). Rudra P. Pradhan et. al (2014) study the Causal nexus between the economic growth, banking development and stock market development with the blend of other macroeconomic variable for the ASEAN countries over a time of 1961-2012. The construct the development 
indices by using principal component analysis and panel vector auto-regressive model for testing the Granger causalities, they argued that there is positive relationship between the economic development and banking development. Therefore for the sound financial system particular banking sector the economic development which is measured through the gross domestic product (GDP), plays vital role.

A strand of literature is evidence that there is positive long-run relationship between economic growth and financial development. All the available studies demonstrate that well developed financial system is growth enhancing and hence confirming with the proposition"more finance, more growth" (Law \& Singh, 2014). In the literature the relationship between the economic development and banking development is available with two views, named "supply-leading" and "demand-following"view later on feed has been developed to make clear these relationship between the economic development and financial development.

\section{Hypotheses of the Study (HP)}

By taking into account the bank's profitability theory that has been developed over the years with the continuous input from the banking area researchers and past banking literature. Hence the present study seeks to investigate following hypotheses for both Chinese and Pakistani banking sector

HP1: There is a significant positive/negative relationship between the deposits of a bank and the bank's performance.

HP2: There is a significant positive relationship between the net Interest Income of a bank and the bank's performances.

HP3: There is a significant Negative relationship between the Non-performing Loans ratio (NPL ratio) of a bank and the bank's Performance.

HP4: There is a significant positive relationship between the Capital adequacy ratio a bank and the bank's performance.

HP5: There is a significant positive/negative relationship between the size of a bank and the bank's performance.

HP6: There is a significant positive relationship between gross domestic product growth and bank performance.

The data for the performance measures, Return on Equity and Return on Assets was collected over the individual banks. The data for the Pakistani banks extracted from the published financial statements while macro economic data extracted from the Federal statistical Bureau of Pakistan (FSBP). However the data for the Chinese banks partly came from China Banking Regulatory Commission (CBRC), reports published by the KPMG a world reknown research company, CSMAR and the data for the macro economic variables comes from the china statistics book 2016. Data on 82 banks in two countries, 61 banks from China and 21 banks from Pakistan were collected. As Mirzaei, Moore, \& Liu (2013); the thesis includes all types of banks instead of only active banks and used data from 2010 to 2017. The country level data for the macro economic variables taken from the country concerned department as for the Pakistan is Federal statistical Bureau of Pakistan (FSBP) while for china National Bureau of Statistics of China (NBSC). 


\section{Results and Discussion}

\subsection{Descriptive Statistics}

Table 1. Descriptive Statistics of the Chinese banking

\begin{tabular}{|c|c|c|c|c|c|}
\hline Variables & $\mathrm{N}$ & Mean & std & Min. & Max \\
\hline $\begin{array}{c}\text { Net Interest } \\
\text { Income (RMB } \\
\text { Million) }\end{array}$ & 352 & 40097 & 86187 & 100 & 493,522 \\
\hline $\begin{array}{c}\text { Total Assets } \\
\text { (RMB Million) }\end{array}$ & 352 & $1.700 \mathrm{e}+06$ & $3.6073+06$ & 6,669 & $2.061 \mathrm{e}+07$ \\
\hline $\begin{array}{c}\text { Deposits (RMB } \\
\text { Million) }\end{array}$ & 352 & $1.272 \mathrm{e}+06$ & $2.826 \mathrm{e}+06$ & 3,205 & $1.556 \mathrm{e}+07$ \\
\hline $\begin{array}{c}\text { Capital } \\
\text { Adequacy Ratio } \\
\text { (\%) }\end{array}$ & 352 & 0.130 & 0.0807 & 0.00940 & 1.503 \\
\hline ROA (\%) & 352 & 0.0109 & 0.00360 & 0.00113 & 0.0232 \\
\hline ROE (\%) & 352 & 0.181 & 0.0624 & -0.0602 & 0.603 \\
\hline GDP (\%) & 352 & 0.0948 & 0.0208 & 0.0736 & 0.142 \\
\hline NPL (\%) & 352 & 70.89 & 37.30 & 1 & 157 \\
\hline
\end{tabular}

The overall sample consists of 352 observations of sixty one banks over the time span of the 2008 to 2015 . These banks include all types of banks, state owned banks, rural development bank, and city banks and this sample also includes all the listed banks of the china. Starting from the return on Equity we feel that the average ROE among the Chinese banks is $18 \%$ which is quite good indication for the progress and growth of the Chinese banking. No doubt China is fastest emerging economy of the world, on one side where the banks are growing so nicely and their higher ROE and huge assets there is one thing noticeable that is the ratio of the non-performing loans which is also 37 percent on average. This is what the most alarming thing in the Chinese banking as in the literature we found studies which empirically shows that non-performing loans are the causes of the financial crisis (see Barseghyan, 2010; Gonzales-Hermosillo, 1999; Zeng, 2012). Another noticeable thing, I found here that in the big four banks which are sharing about which are enjoying almost $32 \%$ weighting of the whole Chinese banking industry, they are quite stable as evident from the standard deviation figure in the above posed table.

\subsection{Regression Analysis of the Chinese Banks}

Table 2. Regression Analysis of ROA of Chinese Banks

\begin{tabular}{|c|c|c|c|c|c|c|c|c|}
\hline Variables & Model 1 & Model 2 & Model 3 & Model 4 & Model 5 & Model 6 & Model 7 & Model 8 \\
\hline \multirow[t]{2}{*}{$\begin{array}{c}\text { Net Interest } \\
\text { Income (RMB } \\
\text { Million) } \\
\end{array}$} & $.02209^{* *}$ & & & & & & & $0.0708 * * *$ \\
\hline & $(0.0501)$ & & & & & & & $(0.0098)$ \\
\hline \multirow[t]{2}{*}{$\begin{array}{l}\text { Total Assets } \\
\text { (RMB } \\
\text { Million) }\end{array}$} & & $0.0231 * *$ & & & & & & $0.015 * *$ \\
\hline & & $(0.0356)$ & & & & & & $(0.0500)$ \\
\hline \multirow[t]{2}{*}{$\begin{array}{l}\text { Deposits } \\
\text { (RMB } \\
\text { Million) }\end{array}$} & & & $.0620^{* *}$ & & & & & $0.0581 * * *$ \\
\hline & & & $(0.0249)$ & & & & & $(0.0020)$ \\
\hline \multirow[t]{2}{*}{$\begin{array}{c}\text { Capital } \\
\text { Adequacy } \\
\text { Ratio (\%) }\end{array}$} & & & & $0.0010^{* * * *}$ & & & & $0.003 * *$ \\
\hline & & & & $(0.00238)$ & & & & $(0.00441)$ \\
\hline
\end{tabular}


The International Journal

ENTREPRENEURSHIP AND SUSTAINABILITY ISSUES

ISSN 2345-0282 (online) http://jssidoi.org/jesi/

2018 Volume 5 Number 3 (June)

http://doi.org/10.9770/jesi.2018.5.4(16)

\begin{tabular}{|c|c|c|c|c|c|c|c|c|}
\hline \multirow[t]{2}{*}{ GDP } & & & & & $0.0132 * * *$ & & & $0.0214 * * *$ \\
\hline & & & & & $(0.0092)$ & & & $(0.0562)$ \\
\hline Listed & & & & & & $(0.00045)$ & & $(0.0552)$ \\
\hline NPL & & & & & & & $(0.0428)$ & $(0.00)$ \\
\hline \multirow[t]{2}{*}{ Constant } & $0.017 * * *$ & $0.029 * * *$ & $0.015 * * *$ & $0.037 * * *$ & $0.012 * * *$ & $0.0210 * * *$ & $0.019 * * *$ & $0.018 * * *$ \\
\hline & $(0.0002)$ & $(0.0031)$ & $(0.0054)$ & $(0.0003)$ & $(0.0089)$ & $(0.00069)$ & $(0.0004)$ & $(0.000044)$ \\
\hline
\end{tabular}

$* * * \mathrm{P}<0.01, * * \mathrm{P}<0.05, * \mathrm{P}<0.10$

The above posed model showed the ordinary least square regression being considering Return on Assets is an indicator of the performance of the Chinese banking sector (Table 2). In these table nine models has been employed by taking every variable one by one and in the last model by taking all the variable altogether to check the influence of the studied variables on the performance of the Chinese banking sector. Starting from the net interest income we found it is positively contributing in the performance of the Chinese banking as the main revenue for the banks comes from the interest. Secondly y excluding the interest income we include the total assets which produced acceptable R-square of 52 percent and positively contributing the performance of the Chinese banks industry. In the third model we put the deposits which are the main source of the banking for generating the profits and found positive correlated with the return on assets. In the last model where all the variables taken together we found all variables are significant except GDP, Capital adequacy ratio (Table 3).

Table 3. Regression Analysis of ROE of Chinese Banks

\begin{tabular}{|c|c|c|c|c|c|c|c|c|}
\hline Variables & Model 1 & Model 2 & Model 3 & Model 4 & Model 5 & Model 6 & Model 7 & Model 8 \\
\hline \multirow{2}{*}{$\begin{array}{c}\text { Net Interest } \\
\text { Income (RMB } \\
\text { Million) } \\
\end{array}$} & $.09708 * *$ & & & & & & & $0.083 * *$ \\
\hline & $(0.00579)$ & & & & & & & $(0.00521)$ \\
\hline \multirow{3}{*}{$\begin{array}{c}\text { Total Assets } \\
\text { (RMB } \\
\text { Million) } \\
\end{array}$} & & -0.06909 & & & & & & -0.02309 \\
\hline & & & & & & & & \\
\hline & & $(0.1634)$ & & & & & & $(0.2308)$ \\
\hline \multirow{3}{*}{$\begin{array}{l}\text { Deposits } \\
\text { (RMB } \\
\text { Million) }\end{array}$} & & & $.2009 *$ & & & & & 0.1809 \\
\hline & & & & & & & & \\
\hline & & & $(0.1009)$ & & & & & $(0.2408)$ \\
\hline \multirow{3}{*}{$\begin{array}{c}\text { Capital } \\
\text { Adequacy } \\
\text { Ratio }(\%) \\
\end{array}$} & & & & $0.134 * * *$ & & & & $0.120 * * *$ \\
\hline & & & & & & & & \\
\hline & & & & $(0.00407)$ & & & & $(0.00321)$ \\
\hline \multirow[t]{2}{*}{ GDP } & & & & & 0.0539 & & & 0.0498 \\
\hline & & & & & $(0.160)$ & & & $(0.155)$ \\
\hline \multirow[t]{2}{*}{ Listed } & & & & & & $0.00905 * * *$ & & $0.00421 * * *$ \\
\hline & & & & & & $(0.00791)$ & & $(0.0081)$ \\
\hline \multirow[t]{2}{*}{ NPL } & & & & & & & $-.000 * * *$ & $-0.000 * * *$ \\
\hline & & & & & & & $(0.00740)$ & $(0.0086)$ \\
\hline \multirow[t]{2}{*}{ Constant } & $0.178 * * *$ & $0.1262 * * *$ & $0.1952 * * *$ & $0.2932 * * *$ & $0.176^{* * *}$ & $0.196 * * *$ & $0.206 * * *$ & $0.207 * * *$ \\
\hline & $(0.00366)$ & $(0.00366)$ & $(0.00363)$ & $(0.00621)$ & $(0.0156)$ & $(0.0121)$ & $(0.0070)$ & $(0.022)$ \\
\hline Observations & 352 & 352 & 352 & 352 & 352 & 352 & 352 & 352 \\
\hline R-Saqured & 0.78 & 0.51 & 0.63 & 0.46 & 0.76 & 0.32 & 0.65 & 0.42 \\
\hline
\end{tabular}

$* * * \mathrm{P}<0.01, * * \mathrm{P}<0.05, * \mathrm{P}<0.10$ 
This table shows the regression analysis for the Chinese banking industry while using return on equity as the measure of the performance. Again firstly each variable is tested independently and later all the variables has been tested in the final model. As per expectation, it is notice that net interest income is significantly contributing in the performance of the Chinese performance which validated the studies see Alessandri and Nelson (2015). More interestingly we found that GDP and Listed do not matter for the performance of the Chinese banking while we measure their influence independently. In the final model which contains all the variables altogether showed that total assets do not have significant role in the performance of the Chinese banking as measured by the roe which validates the concept too big to failure.

\subsection{Pakistani Banks Descriptive Statitics}

This portion reveals the findings regarding the Pakistani banking sector which is enjoying the intense competition not only with the domestic players but with the international player in the sector. Pakistani baking is full diverse sector with significant foreign bank, domestic private banks and state owned banks. For more details information below is the descriptive statistics of the Pakistani banking sector (Table 4).

Table 4. Descriptive Statistics of the Pakistani banking

\begin{tabular}{|c|c|c|c|c|c|}
\hline Variables & $\mathrm{N}$ & Mean & Std & Min. & Max \\
\hline $\begin{array}{c}\text { Deposits (Rupee } \\
\text { Million) }\end{array}$ & 68 & 96348 & 125512 & 127.7 & 591907 \\
\hline $\begin{array}{c}\text { Total Assets } \\
\text { (RMB Million) }\end{array}$ & 68 & $1.086 \mathrm{e}+08$ & $1.447 \mathrm{e}+08$ & 567,131 & $7.622 \mathrm{e}+08$ \\
\hline $\begin{array}{c}\text { Net Interest } \\
\text { Income (RMB } \\
\text { Million) }\end{array}$ & 68 & $6.791 \mathrm{e}+06$ & $9.385 \mathrm{e}+06$ & 30,801 & $5.075 \mathrm{e}+07$ \\
\hline ROE(\%) & 68 & 0.00278 & 0.0047 & -0.0251 & 0.0322 \\
\hline ROA(\%) & 68 & 0.0167 & 0.0415 & -0.276 & 0.108 \\
\hline NPL(\%) & 68 & 0.132 & 0.171 & $1.58 \mathrm{e}-05$ & 0.803 \\
\hline GDP(\%) & 68 & 0.0383 & 0.00651 & 0.0258 & 0.0554 \\
\hline
\end{tabular}

From this table, we see that the size of the Pakistani banking is quite rich and they are earning good performance on average if we have look on the ROA and ROE. In few years they do have abnormal loss which is due to the financial crisis. It is fact that Pakistan is not affected strongly with the financial crisis of 2008, but they still affected by the financial crunch. As comparison with china, Chinese banks are performing well as their economic growth support them to perform much better than Pakistani banking. Secondly china is enjoying double growth rate as compare to Pakistani banking. The most common descriptive is the issue of non-performing loans. Pakistani banking is also generating enough non-performing loans which are bad for the growth of the Pakistani banking (Table 5). 


\subsection{Regression Analysis of the Pakistani Banks}

Table 5. Regression Analysis of ROA of Pakistani Banks

\begin{tabular}{|c|c|c|c|c|c|c|c|}
\hline Variables & Model 1 & Model 2 & Model 3 & Model 4 & Model 5 & Model 6 & Model 7 \\
\hline \multirow[t]{2}{*}{$\begin{array}{l}\text { Deposits } \\
\text { (RMB } \\
\text { Million) } \\
\end{array}$} & $0.08208 * * *$ & & & & & & \\
\hline & $(0.009)$ & & & & & & \\
\hline \multirow[t]{2}{*}{$\begin{array}{c}\text { Total Assets } \\
\text { (RMB } \\
\text { Million) }\end{array}$} & & $0.04811 * * *$ & & & & & \\
\hline & & $(0.0076)$ & & & & & \\
\hline \multirow[t]{2}{*}{$\begin{array}{c}\text { Net Interest } \\
\text { Income (RMB } \\
\text { Million) } \\
\end{array}$} & & & $0.00810 * *$ & & & & \\
\hline & & & $(0.0067)$ & & & & \\
\hline \multirow[t]{2}{*}{ NPL Ratio } & & & & $-0.0556 * * *$ & & & \\
\hline & & & & $(0.0184)$ & & & \\
\hline \multirow[t]{2}{*}{ GDP } & & & & & 0.111 & & \\
\hline & & & & & $(0.495)$ & & \\
\hline \multirow[t]{2}{*}{ OW } & & & & & & $0.00944 * *$ & \\
\hline & & & & & & $(0.00422)$ & \\
\hline \multirow[t]{2}{*}{ Constant } & $0.101 * *$ & $0.0966 * *$ & $0.03400 * *$ & $0.0938 * *$ & 0.210 & 0.00537 & $0.261 * * *$ \\
\hline & $(0.00397)$ & $(0.00392)$ & $(0.00387)$ & $(0.00395)$ & $(0.0192)$ & $(0.00904)$ & $(0.0225)$ \\
\hline Observations & 168 & 168 & 168 & 168 & 168 & 168 & 168 \\
\hline R-Saqured & 0.43 & 0.51 & 0.67 & 0.45 & 0.76 & 0.63 & 0.58 \\
\hline
\end{tabular}

$* * * \mathrm{P}<0.01, * * \mathrm{P}<0.05, * \mathrm{P}<0.10$

The above posed table shows the regression results of the individual variables one by one and in the last model the effect of all the studied variables as we did for the Chinese banking sector. By employing the regression analysis, we found that deposits do have the positive influence in the performance of the Pakistani banking which ultimately increases their interest income which is also positive with the individual effect and along with the other variables in the last model. The most common thing $\mathrm{w}$ found is that the non-performing loans are significant influencing the performance of the Pakistani banking in the last regression model which carries the R-square of 0.82 that means higher the non-performing loans lower the performance of the banks (Marco Sorge et. al (2004) and Jakubik and Reininger (2013).

Table 6. Regression Analysis of ROE of Pakistani Banks

\begin{tabular}{|c|c|c|c|c|c|c|c|}
\hline Variables & Model 1 & Model 2 & Model 3 & Model 4 & Model 5 & Model 6 & Model 7 \\
\hline $\begin{array}{c}\text { Deposits } \\
\text { (RMB } \\
\text { Million) }\end{array}$ & $0.0869^{*}$ & & & & & & \\
\hline $\begin{array}{c}\text { Total Assets } \\
\text { (RMB } \\
\text { Million) }\end{array}$ & $(0.078)$ & & $0.05672 * * *$ & & & & \\
\hline $\begin{array}{c}\text { Net Interest } \\
\begin{array}{c}\text { Income (RMB } \\
\text { Million) }\end{array}\end{array}$ & & $(0.000764)$ & & & & & \\
\hline & & $0.07110^{* * *}$ & & & & \\
\hline
\end{tabular}




\begin{tabular}{|c|c|c|c|c|c|c|c|}
\hline \multirow[t]{2}{*}{ NPL Ratio } & & & & $-0.00335 * * *$ & & & \\
\hline & & & & $(0.00214)$ & & & \\
\hline \multirow[t]{2}{*}{ GDP } & & & & & $0.0131 * *$ & & \\
\hline & & & & & $(0.0556)$ & & \\
\hline \multirow[t]{2}{*}{ OW } & & & & & & $0.432 * * *$ & $0.416 * *$ \\
\hline & & & & & & $(0.0153)$ & $(0.0243)$ \\
\hline \multirow[t]{2}{*}{ Constant } & $0.250 * * *$ & $0.160 * *$ & $0.562 * * *$ & $0.234 * * *$ & $0.779 * * *$ & $0.363 * * *$ & $0.9011 * * *$ \\
\hline & $(0.000461)$ & $(0.000433)$ & $(0.000426)$ & $(0.000426)$ & $(0.00216)$ & $(0.00056)$ & $(0.00211)$ \\
\hline Observations & 168 & 168 & 168 & 168 & 168 & 168 & 168 \\
\hline R-Saqured & 0.65 & 0.32 & 0.63 & 0.48 & 0.67 & 0.69 & 0.78 \\
\hline
\end{tabular}

$* * * \mathrm{P}<0.01, * * \mathrm{P}<0.05, * \mathrm{P}<0.10$

From Table 6, once we changed the performance measure which is Return on Equity (ROE) instead of the Return on Assets (ROA) it shows that there Total assets are significantly influencing the performance of the Pakistani banking sector. Meanwhile we also observed that again non-performing loans have their constant negative influence on the performance of the Pakistani banking industry. The R-square of the all models, either the variables are tested individually or in the group within the acceptance range.

\section{Conclusions}

This study core aims to identify the main factors that can affect Chinese and Pakistani banks performance and to what extent these determinants exert impact on Chinese and Pakistani banks performance. To achieve this objective, the existing studies on bank performance have been reviewed and it is summarized that the performance of bank is usually expressed as a function of internal and external determinants. The internal determinants refers to the factors originate from bank accounts (balance sheets and/or profit and loss accounts) and therefore could be termed micro or bank-specific determinants of profitability. Whereas external determinants are refers to variables that are not controlled by the bank management but reflect the economic and legal environment that affects the operation and performance of financial institutions. Empirical results from previous studies conclude that both internal and external factors significantly influence the performance of banks. There are number of explanatory variables that have been utilized to measure the performance of banks, according to the nature and purpose of each study. Studies for the bank specific variables employ variables such as Total assets, capital, asset non-performing loans, income diversification or costs etc while for external determinants; GDP have been widely used to capture the external factors influence on the performance of banks. The recent financial crises push the scholars to study the governance issues in the banking industry and strand of literature is available in this regard.

\section{References}

Chi, Q., \& Li, W. (2017). Economic policy uncertainty, credit risks and banks' lending decisions: Evidence from Chinese commercial banks. China Journal of Accounting Research, 10(1), 33-50. http://doi.org/doi:10.1016/j.cjar.2016.12.001

Moutsianas, K. A., \& Kosmidou, K. (2016). Bank earnings volatility in the UK: Does size matter? A comparison between commercial and investment banks. Research in International Business and Finance, 38, 137-150. http://doi.org/doi:10.1016/j.ribaf.2016.03.013

Poghosyan, T., Werger, C., \& de Haan, J. (2016). Size and support ratings of US banks. The North American Journal of Economics and Finance, 37, 236-247. http://doi.org/doi:10.1016/j.najef.2016.05.006 
Laeven, L., Ratnovski, L., \& Tong, H. (2016). Bank size, capital, and systemic risk: Some international evidence. Journal of Banking \& Finance, 69, S25-S34. http://doi.org/doi:10.1016/i.jbankfin.2015.06.022

Aydemir, R., \& Ovenc, G. (2016). Interest rates, the yield curve and bank profitability in an emerging market economy. Economic Systems, 40(4), 670-682. http://doi.org/doi:10.1016/j.ecosys.2016.04.003

Abou-El-Sood, H. (2016). Are regulatory capital adequacy ratios good indicators of bank failure? Evidence from US banks. International Review of Financial Analysis, 48, 292-302. http://doi.org/doi:10.1016/j.irfa.2015.11.011

Berger, A. N., Herring, R. J., \& Szegö, G. P. (1995). The role of capital in financial institutions. Journal of Banking \& Finance, 19(3-4), 393-430. http://doi.org/doi:10.1016/0378-4266(95)00002-x

Bichsel, R., \& Blum, J. (2004). The relationship between risk and capital in Swiss commercial banks: a panel study. Applied Financial Economics, 14(8), 591-597. http://doi.org/doi:10.1080/0960310042000233881

Barthélémy, V., \& Michel, P. (2003). Education supply, economic growth and the dynamics of skills. Recherches Économiques de Louvain, 69(2), 145. http://doi.org/doi:10.3917/rel.692.0145

Zhang, D., Cai, J., Dickinson, D. G., \& Kutan, A. M. (2016). Non-performing loans, moral hazard and regulation of the Chinese commercial banking system. Journal of Banking \& Finance, 63, 48-60. http://doi.org/doi:10.1016/j.jbankfin.2015.11.010

Jiang, C., Yao, S., \& Feng, G. (2013). Bank ownership, privatization, and performance: Evidence from a transition country. Journal of Banking \& Finance, 37(9), 3364-3372. http://doi.org/doi:10.1016/j.jbankfin.2013.05.009

Foos, D., Norden, L., \& Weber, M. (2010). Loan growth and riskiness of banks. Journal of Banking \& Finance, 34(12), 2929-2940. http://doi.org/doi:10.1016/j.jbankfin.2010.06.007

Demirguc-Kunt, A. (1989). Modeling Large Commercial-Bank Failures: A Simultaneous-Equation Analysis. Working Paper (Federal Reserve Bank of Cleveland). http://doi.org/doi:10.26509/frbc-wp-198905

Furlong, F. T., \& Keeley, M. C. (1989). Capital regulation and bank risk-taking: A note. Journal of Banking \& Finance, 13(6), 883-891. http://doi.org/doi:10.1016/0378-4266(89)90008-3

Soedarmono, W., \& Tarazi, A. (2015). Competition, Financial Intermediation and Riskiness of Banks: Evidence from Asia Pacific. SSRN Electronic Journal. http://doi.org/doi:10.2139/ssrn.2560099

Fink, G., Haiss, P., \& Vukšić, G. (2009). Contribution of financial market segments at different stages of development: Transition, cohesion and mature economies compared. Journal of Financial Stability, 5(4), 431-455. http://doi.org/doi:10.1016/j.jfs.2008.05.002

Beck, T., \& Hesse, H. (2006). Bank efficiency, ownership, and market structure: why are interest spreads so high in Uganda?. (Policy research working paper; No. 4027). Washington: The World Bank, Development Research Group, Finance Team https://pure.uvt.nl/ws/files/1107753/Bank_Efficiency_Ownership_and_market_Structure.pdf

Garcia, V. F., \& Liu, L. (1999). Macroeconomic determinants of stock market development. Journal of Applied Economics, 2(1). https://www.ucema.edu.ar/publicaciones/download/volume2/garcia liu.pdf

Levine, R., \& Zervos, S. (1998). Stock markets, banks, and economic growth. American economic review, 537-558 http://links.jstor.org/sici?sici=0002-8282\%28199806\%2988\%3A3\%3C537\%3ASMBAEG\%3E2.0.CO\%3B2-9

Naceur, S. B., \& Ghazouani, S. (2007). Stock markets, banks, and economic growth: Empirical evidence from the MENA region. Research in International Business and Finance, 21(2), 297-315. http://doi.org/doi:10.1016/j.ribaf.2006.05.002

Yartey, C. A. (2008). The Determinants of Stock Market Development in Emerging Economies: Is South Africa Different? IMF Working Papers, 08(32), 1. http://doi.org/doi:10.5089/9781451868944.001 
The International Journal

ENTREPRENEURSHIP AND SUSTAINABILITY ISSUES

ISSN 2345-0282 (online) http://jssidoi.org/jesi/

2018 Volume 5 Number 3 (June)

http://doi.org/10.9770/jesi.2018.5.4(16)

Fung, M. K. (2009). Financial development and economic growth: Convergence or divergence? Journal of International Money and Finance, 28(1), 56-67. http://doi.org/doi:10.1016/j.jimonfin.2008.08.001

Pedroni, P. (2001). Purchasing Power Parity Tests in Cointegrated Panels. Review of Economics and Statistics, 83(4), 727-731. http://doi.org/doi:10.1162/003465301753237803

Law, S. H., \& Singh, N. (2014). Does too much finance harm economic growth? Journal of Banking \& Finance, 41, 36-44. http://doi.org/doi:10.1016/i.jbankfin.2013.12.020

Jiaxin XU is Ph.D student of Liaoning Technical University, research orientation: theory and method of management science

Naiwen LI is Ph.D, Professor, Deputy Dean, School of Business Administration, Liaoninig Technical University, Ph.D tutor, engaged in human resource management and safety management research.

Muhammad Ishfaq AHMAD is the Assistant Professor at Lahore Business School, The University of Lahore. He received his PhD from Liaoning Technical University, China. He won outstanding International Awrad given by the Chinese Ministry of Education 2016. Research interests: corporate governance, Corporate Social responsibility and banks performance.

ORCID ID: orcid.org/ 0000-0003-1468-1073

Register for an ORCID ID:

https://orcid.org/register

Copyright (C) 2018 by author(s) and VsI Entrepreneurship and Sustainability Center This work is licensed under the Creative Commons Attribution International License (CC BY). http://creativecommons.org/licenses/by/4.0/

(c) (†) Open Access 